\title{
Microbiology research at the systems biology and bioinformatics - 2019 (SBB-2019) school
}

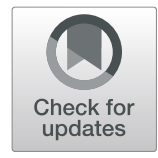

Yuriy L. Orlov ${ }^{1,2,3,4^{*}}$, Alexander N. Ignatov ${ }^{3,5}$, Elvira R. Galieva² and Oxana B. Dobrovolskaya 3,4

From 11th International Young Scientists School "Systems Biology and Bioinformatics" - SBB-2019

Novosibirsk, Russia. 24-28 June 2019

This Special Issue of BMC Microbiology "Systems Biology and Bioinformatics" presents the materials discussed at the 11-th Young Scientists School "Systems Biology and Bioinformatics"-2019 (SBB-2019) in Novosibirsk, Russia (http://conf.bionet.nsc.ru/sbb2019/en/). These Young Scientists' Schools on bioinformatics have been organized every year since 2008 by the Institute of Cytology and Genetics of the Siberian Branch of the Russian Academy of Sciences and Novosibirsk State University $[1,2]$. To accompany this Special Issue on microbiology, parallel special journal issues in the fields of genomics, bioinformatics, and medical genomics were published as a part of SBB-2019 series in BioMed Central journals: BMC Genomics, BMC Medical Genomics, BMC Genetics, BMC Medical Genetics, and BMC Bioinformatics (https://bmcbioinformatics.biomedcentral. com/articles/supplements/volume-21-supplement-11).

The SBB Schools in Novosibirsk are satellite training meetings for young scientists and $\mathrm{PhD}$ students, which are organized either as satellite events for BGRSISB (Bioinformatics of Genome Regulation and Structure \Systems Biology) conferences series $[3,4]$ or as independent events $[2,5]$. The Schools were accompanied and complemented by the publication of special journal issues in BMC Microbiology [6] and other BioMed Central journals [3, 4].

This special issue contains the study by S.E. Peltek and co-authors [7] describing microbial life habitats in unique volcano caldera environment.

\footnotetext{
* Correspondence: orlov@d-health.institute

${ }^{1}$ The Digital Health Institute, I.M. Sechenov First Moscow State Medical University of the Ministry of Health of the Russian Federation (Sechenov University), 119146 Moscow, Russia

${ }^{2}$ Novosibirsk State University, 630090 Novosibirsk, Russia

Full list of author information is available at the end of the article
}

The caldera of the Uzon Volcano (Kamchatka Peninsula, Russia) is a region with active hydrothermal activity, which contains outlets of unique natural hydrothermal petroleum [8] with distinct microbiota. Hydrothermal petroleum is the oil found in natural outlets within active hydrothermal fields [8, 9]. According to carbon ${ }^{14} \mathrm{C}$ dating, hydrothermal petroleum from various regions of the Earth is modern in geological scale, with the oldest sample being 29,000 years old [10]. The Uzon petroleum is the youngest on Earth, with the initial time estimate at 1000 years, and later found to be only 50 years old [11].

The composition of the Uzon oil was investigated in several studies [12]. Uzon oil has a unique make-up, with low proportion of heavy fractions and relatively high content of saturated hydrocarbons [11]. Correspondingly, the microbial communities of the "oil site" have diverse composition profiles, living at almost boiling temperatures (up to $97^{\circ} \mathrm{C}$ ), significant oscillations of $\mathrm{pH}$, and high content of sulfides, arsenic, antimony, and mercury in water.

In this journal issue, Peltek et al. [7] analyzed the composition, structure, unique genetic features and the metabolic pathways of the microbial communities at the oil site. The authors present evidence of diverse metabolic pathways of hydrocarbon degradation by microorganisms being operational within the local microbiota. Interestingly, the authors found statistically significant relationships between geochemical parameters, taxonomic composition and the completeness of metabolic pathways [7]. Metabolic pathways of hydrocarbon oxidation were found to prevail in the studied communities, which corroborated the hypothesis on abiogenic synthesis of Uzon hydrothermal petroleum. 
In previous research, the majority of the studied oil sites contained representatives of Actinomycetales (Actinobacteria). Typically, the geochemical parameters defined the structure and metabolic potential of microbial communities. This is confirmed by the genome sequence of Anoxybacillus flavithermus KU2-6-11 isolated from hot-spring in Uzon caldera, which was published recently [13]. Other prior work includes the microbial community analysis of the Uzon caldera springs, which was presented earlier at the BMC special journal issues accompanying a previous BGRS conference in 2014 [14]. The same researchgroup, A.V. Bryanskaya et al., published description of environmental factors for the composition of microbial communities of saline lakes in BMC Microbiology special issue [15]. While this journal issue has been in preparation, novel thermophilic Aeribacillus bacteriophage AP45 was isolated from the Kamchatka [16] as well as a thermophilic bacterium Geobacillus icigianus [17].

Going back to the BGRS post-conference issues, we would like to note fundamental systems biology work by late Dr. Vitaly A. Likhoshvai on the mathematical modeling of metabolic systems in Escherichia coli cells, which was published in BMC Microbiology [6]. This research showed that the modeling of relevant environmental factors can increase a heuristic value of a genomic study of the microbial communities. The manuscript by V.A.Likhoshvai, which has been finalized by his co-authors, was published in the parallel BMC Bioinformatics special issue after SBB-2019 School [18]. Here it is also appropriate to refer to the recent publication by V.A. Likhoshvai on dynamical model of noninherited antibiotic tolerance of microorganisms [19].

We aim to support international exchanges and education in bioinformatics and systems biology in the forms of the Schools for young scientists and make new results open keeping traditions of the BGRS conference series $[1,2,5,20]$.

\section{Acknowledgements}

We thank Prof. T.V. Tatarinova and A.V. Baranova for the editorial work on SBB-2019 journal issues. We are grateful to Academician N.A. Kolchanov for the organization of the "Systems Biology and Bioinformatics"-2019 School in Novosibirsk, Russia. We thank Dr. O. Tolmachov for the help with the manuscript preparation.

The publication has been prepared with the support of the RUDN University Program 5-100 (Recipients: YO, Al, OD).

\section{About this supplement}

This article has been published as part of BMC Microbiology Volume 20 Supplement 2, 2020: Selected Topics in "Systems Biology and Bioinformatics" - 2019: microbiology. The full contents of the supplement are available online at - https://bmcmicrobiol.biomedcentral.com/articles/supplements/ volume-20-supplement-2.

\section{Authors' contributions}

YO is guest editor of SBB-2019 issues. Al, EG and OD are the invited editors and the organizing committee members. All the authors read, revised and approved the final manuscript.

\section{Authors' information}

Yuriy L. Orlov, the conference organizer and guest editor of the SBB-2019

special issues orlov@d-health.institute.

Elvira R. Galieva, organizing committee member.

Alexander N. Ignatov, organizing committee member.

Oxana B. Dobrovolskaya, organizing committee member.

Funding

Publication of this article was not covered by sponsorship.

\section{Competing interests}

The authors declare that they have no competing interests.

\section{Author details}

${ }^{1}$ The Digital Health Institute, I.M. Sechenov First Moscow State Medical University of the Ministry of Health of the Russian Federation (Sechenov University), 119146 Moscow, Russia. ${ }^{2}$ Novosibirsk State University, 630090 Novosibirsk, Russia. ${ }^{3}$ Agrarian and Technological Institute, Peoples' Friendship University of Russia (RUDN University), 117198 Moscow, Russia. ${ }^{4}$ Institute of Cytology and Genetics SB RAS, 630090 Novosibirsk, Russia.

${ }^{5}$ PhytoEngineering R\&D Centre, 141880, Moscow Region, Moscow, Russia.

Published: 24 November 2020

\section{References}

1. Baranova AV, Orlov YL. The papers presented at 7th young scientists school "systems biology and bioinformatics" (SBB'15): introductory note. BMC Genet. 2016;17:S20. https://doi.org/10.1186/s12863-015-0326-5.

2. Orlov YL, Tatarinova TV, Zakhartsev MV, Kolchanov NA. Introduction to the 9 th young scientists school on systems biology and bioinformatics (SBB'2017). J Bioinforma Comput Biol. 2018;16(1):1802001. https://doi.org/10. 1142/S0219720018020018.

3. Tatarinova TV, Chen M, Orlov YL. Bioinformatics research at BGRS-2018. BMC Bioinformatics. 2019;20:33. https://doi.org/10.1186/s12859-018-2566-7.

4. Orlov YL, Galieva ER, Melerzanov AV. Computer genomics research at the bioinformatics conference series in Novosibirsk. BMC Genomics. 2019; 20(Suppl 7):537. https://doi.org/10.1186/s12864-019-5846-3.

5. Orlov YL, Galieva ER, Tatarinova TV. Bioinformatics research at SBB-2019. BMC Bioinformatics. 2020;21 (Suppl 11):366. https://doi.org/10.1186/s12859020-03712-1.

6. Khlebodarova TM, Ree NA, Likhoshvai VA. On the control mechanisms of the nitrite level in Escherichia coli cells: the mathematical model. BMC Microbiol. 2016;16(Suppl 1):7. https://doi.org/10.1186/s12866-015-0619-X.

7. Peltek SE, Bryanskaya AV, Uvarova YE, Rozanov AS, Ivanisenko TV, Ivanisenko VA, Lazareva EV, Saik OV, Efimov VM, Zhmodik SM, Taran OP, Slynko NM, Shekhovtsov SV, Parmon VN, Dobretsov NL, Kolchanov NA. Young «oil site» of the Uzon Caldera as a habitat for unique microbial life. BMC Microbiol. 2020;20(Suppl 2). https://doi.org/10.1186/s12866-020-02012-1.

8. Dobretsov NL, Lazareva EV, Zhmodik SM, Bryanskaya AV, Morozova W, Tikunova NV, et al. Geological, hydrogeochemical, and microbiological characteristics of the oil site of the Uzon caldera (Kamchatka). Russ Geol Geophys. 2015;56(1-2):39-63.

9. Didyk BM, Simoneit BRT. Hydrothermal oil of Guaymas Basin and implications for petroleum formation mechanisms. Nature. 1989;342(6245): 65-8. https://doi.org/10.1038/342065a0.

10. Simoneit BRT, Kvenvolden KA. Comparison of $14 \mathrm{C}$ ages of hydrothermal petroleums. Org Geochem. 1994;21 (5):525-9. https://doi.org/10.1016/01466380(94)90103-1.

11. Varfolomeev SD, Karpov GA, Synal H-A, Lomakin SM, Nikolaev EN. The youngest natural oil on earth. Dokl Chem. 2011;438(1):144-7. https://doi. org/10.1134/S0012500811050053

12. Galimov EM, Sevast'yanov VS, Karpov GA, Kamaleeva Al, Kuznetsova OV, Konopleva IV, Vlasova LN. Hydrocarbons from a volcanic area. Oil seeps in the Uzon caldera, Kamchatka. Geochem Int. 2015;53:1019-27. https://doi. org/10.1134/S0016702915120046.

13. Rozanov AS, Korzhuk AV, Bryanskaya AV, Peltek SE. Draft genome sequence of Anoxybacillus flavithermus KU2-6-11 isolated from hot-spring in Uzon caldera (Kamchatka, Russia). Data Brief. 2017;16:758-61. https://doi.org/10. 1016/j.dib.2017.11.095.

14. Rozanov AS, Bryanskaya AV, Malup TK, Meshcheryakova IA, Lazareva EV, Taran OP, Ivanisenko TV, Ivanisenko VA, Zhmodik SM, Kolchanov NA, Peltek 
SE. Molecular analysis of the benthos microbial community in Zavarzin thermal spring (Uzon Caldera, Kamchatka, Russia). BMC Genomics. 2014; 15(Suppl 12):S12. https://doi.org/10.1186/1471-2164-15-S12-S12.

15. Bryanskaya AV, Malup TK, Lazareva EV, Taran OP, Rozanov AS, Efimov VM, Peltek SE. The role of environmental factors for the composition of microbial communities of saline lakes in the Novosibirsk region (Russia). BMC Microbiol. 2016;16:S4. https://doi.org/10.1186/s12866-015-0618-y.

16. Morozova V, Bokovaya O, Kozlova Y, Kurilshikov A, Babkin I, Tupikin A, Bondar A, Ryabchikova E, Brayanskaya A, Peltek S, Tikunova N. A novel thermophilic Aeribacillus bacteriophage AP45 isolated from the valley of geysers, Kamchatka: genome analysis suggests the existence of a new genus within the Siphoviridae family. Extremophiles. 2019;23(5):599-612. https://doi.org/10.1007/s00792-019-01119-2.

17. Kulyashov M, Peltek SE, Akberdin IR. A genome-scale metabolic MODEL of 2,3-butanediol production by thermophilic Bacteria Geobacillus icigianus. Microorganisms. 2020;8(7):E1002. https://doi.org/10.3390/ microorganisms8071002

18. Likhoshvai VA, Golubyatnikov VP, Khlebodarova TM. Limit cycles in models of circular gene networks regulated by negative feedback loops. BMC Bioinformatics. 2020;21(Suppl 11):255. https://doi.org/10.1186/s12859-02003598-z.

19. Khlebodarova TM, Likhoshvai VA. Molecular mechanisms of non-inherited antibiotic tolerance in Bacteria and Archaea. Mol Biol (Mosk). 2019;53(4): 531-40. (In Russian). https://doi.org/10.1134/S0026898419040050.

20. Orlov YL, Voropaeva EN, Chen M, Baranova AV. Medical genomics at the systems biology and bioinformatics (SBB-2019) school. BMC Med Genet. 2020;13(Suppl 8):127. https://doi.org/10.1186/s12920-020-00786-X.

\section{Publisher's Note}

Springer Nature remains neutral with regard to jurisdictional claims in published maps and institutional affiliations.

Ready to submit your research? Choose BMC and benefit from:

- fast, convenient online submission

- thorough peer review by experienced researchers in your field

- rapid publication on acceptance

- support for research data, including large and complex data types

- gold Open Access which fosters wider collaboration and increased citations

- maximum visibility for your research: over $100 \mathrm{M}$ website views per year

At $\mathrm{BMC}$, research is always in progress.

Learn more biomedcentral.com/submissions 